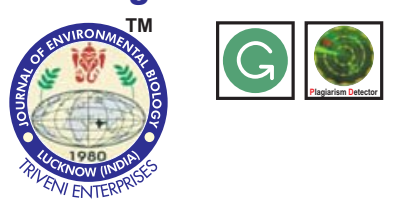

\title{
Cadmium tolerance and its enhanced accumulation potential of Arundo donax by EDTA
}

Authors Info

P.J. Khankhane, A. Tabassum* and $A$. Patel

ICAR-Directorate of Weed Research, Maharajpur, Jabalpur-482 004, India

${ }^{*}$ Corresponding Author Email : aasfatabassum@gmail.com

Key words

Cadmium accumulation,

Chelating agent,

Chlorophyll,

Giant reed

Publication Info

Paper received: 02.04. 2015

Revised received: 15.06 .2015

Re-revised received: 22.01.2016

Accepted: 13.07.2016

\section{Abstract}

Aim: Cadmium accumulation in soil and water is becoming a major environmental problem due to high toxicity of $\mathrm{Cd}$ and its high mobility from soil to crops and further to food chain. In order to remediation its bioavailability in soil, tolerance ability of potential plant are major concern at metalliferrous sites. The present investigation was, thus, carried out with an objective to test the tolerance ability of Arundo donax (Giant reed) to cadmium with or without EDTA.

Methodology: The present study was conducted during 2013 to elucidate the growth response of Arundo irrigated with different levels of cadmium $\left(0,100,200,400,800\right.$ and $\left.1200 \mathrm{mg} \mathrm{l}^{-1}\right)$. In addition, to enhance the phytoaccumulation potential of cadmium, ethylene diaminetetraacetate (EDTA) aqueous solution at three rates $\left(0,3\right.$ and $\left.6 \mathrm{mgl}^{-1}\right)$ was applied to the plant.

Results: The results indicated that Arundo donax tolerated Cd upto $400 \mathrm{mg} \mathrm{l}^{-1}$ without showing any adverse effect in terms of plant height, number of tillers, leaf area and total chlorophyll. The plant accumulated cadmium from spiked medium to shoot and root with bioconcentration factor $(B C)$ of 1.44 and 1.96, respectively, at $200 \mathrm{mg} \mathrm{l}^{-1} \mathrm{Cd}$ exposure. EDTA significantly enhanced $12.8 \%$ dry weight of shoot and enhanced 2-3 times cadmium accumulation in root as compared to control (No EDTA). At elevated cadmium concentration $\left(400 \mathrm{mg} \mathrm{l}^{-1}\right)$, the $B C$ factor of 7.74 in root and 0.89 in shoot was recorded under EDTA application of 3 $\mathrm{mg} \mathrm{l}^{-1}$. Except root length, no adverse effect of EDTA was observed on plant growth.

Interpretation: Arundo donax is a perennial weedy plant which grows at moist places throughout the year in India. Giant reed tolerated high concentration of cadmium, and in the presence of EDTA enhanced $\mathrm{Cd}$ uptake was 2-3 times in its root and translocation to shoot part also. Having high tolerance ability, combination with optimum dose of EDTA ( $\left.3 \mathrm{mg} \mathrm{l}^{-1}\right)$ Arundo has implications for phytoremediation of less bioavailable cadmium contaminated sites.

\section{Phytoremediation of $\mathrm{Cd}$}

$\sqrt{ }$

Tolerence ability of Arundo donax

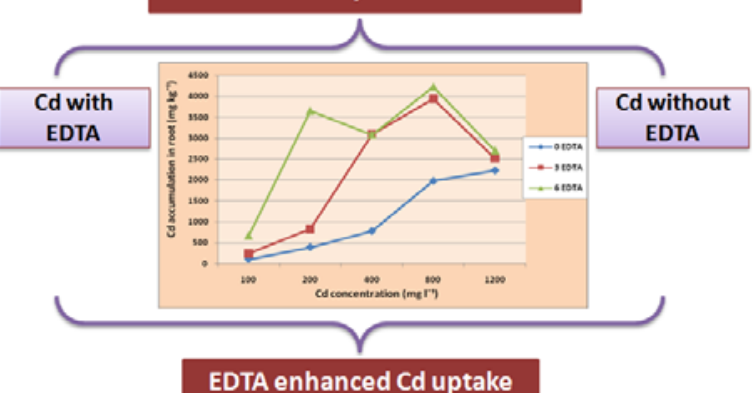

EDTA enhanced Cd uptake

Arundo has a implication for

phytoremediation of less bio-available Cd contaminated sites 


\section{Introduction}

Cadmium is a heavy metal naturally present in soil at concentrations slightly more than $1 \mathrm{mg} \mathrm{kg}^{-1}$ (Prabavathi et al., 2011; Singh and Kumar et al., 2014). Continuous use of $\mathrm{Cd}$ contaminated water for irrigation is bound to result its entry in food chain. The most important sources that cause Cd pollution are mine spoils, metal industry, zinc smelting, plastics mailed home tools, fossil fuels of vehicles and sewers (Demirezen and Aksoy, 2004; Martin and Rubey, 2004). It has been estimated that over $2 \times 10^{9} \mathrm{t}(\mathrm{MT})$ of environmentally hazardous mined and processed wastes are generated per year due to mining activities in India (Singh et al., 2003). Owing to its export demand, the production of cadmium as a byproduct from mining and smelting activities will however continue as long as zinc and lead are produced (IBM, 2012). Cadmium is present in zinc ore deposits which is recovered as a by-product in sphalerite containing $\mathrm{Cd}$ ranged from 0.03 to $9.0 \%$ on weight basis. $\mathrm{Cd}$ is one of the most important pollutants to be considered in terms of food chain contamination (Lane et al., 2015). Besides this, use in industries for corrosion-protection coating and nickel cadmium batteries has recently been reported to be the cause of cadmium pollution in water environment in India (CPCB, 2007).

Mined and industrial drain merged river water is increasingly utilized as a valuable resource for irrigation in urban and peri-urban agriculture during dry period. Continuous irrigation of agricultural land with industrial, sewage and mined waste water may cause heavy metal accumulation in soil and vegetables (Singh et al., 2004; Sharma et al., 2007; Marshall et al., 2007). In a highly publicized episode of $\mathrm{Cd}$ poisoning of humans as itai-itai disease reported in Japan, the source of excessive $\mathrm{Cd}$ affected individuals was from rice irrigated with water from a river contaminated by zinc mining operations (Tscuchya, 1978).

Cadmium in agricultural soil is relatively immobile but become mobile under acidic conditions. Once the cadmium added to the soil remains for a long time and it may take about 100 to 1000 years for leaching of cadmium from the soil to half (CPCB, 2007). In sediment, cadmium is mainly associated with small particles of organic materials. Thus high content of cadmium is found in areas, where sedimentation rate of organic particles is comparatively higher (CPCB, 2007). These effects limit the marketing of agricultural products and reduce the profitability of the agricultural industry. In recent years, many export consignments of cephalopods processed in Gujarat region of India were rejected on account of high levels of cadmium (Murthy etal., 2009).

Removal and phytostabilisation of cadmium at contaminated source is easier than from areas where these get accumulated by adsorption (Samra, 2007). The use of fast growing weedy plant producing efficient biomass such as Arundo donax is highly desirable for phyto-extraction of cadmium from contaminated soil and waters. Arundo is cultivable throughout India locally called as natkhat and is also grown in Asian countries (Papazoglou et al., 2005; Mirza et al., 2010). The cadmium content is typically in the range of 3-150 mg I-1 and even higher range of $10-500 \mathrm{mg} \mathrm{l}^{-1}$ as reported by Mar and Okazaki, 2012 in rock phosphate used in phosphatic fertilizers. The studies indicated that use of phosphate fertilizers is also route of $\mathrm{Cd}$ addition in soil (Merry and Tiller, 1991). Unless there is a specific decadmiation treatment during the manufacturing of phosphate fertilizer, the final product retains most of the original cadmium content. Under alkaline condition, $\mathrm{Cd}$ is relatively immobile, having high capacity to lock up and arrest their mobility in calcarious site affecting efficiency of phytoextraction. Phytoremediation enhanced by chemical chelators, is advocated to get rid of this drawback (Farid et al., 2013; Wuana and Okieimen, 2010; Thayalakumaran et al., 2000).

In previous work of screening plant species, among weedy plants, Arundo donax has showen higher bioaccumulation factor for lead and manganese at contaminated sites (Khankhane and Varshney, 2011). The major issue hampering the efficiency of plant to remediate is that most of the heavy metals in soil are static and their accessibility and phytoextraction speed is confined by diffusion and solubility to roots surface. Chemically enhancements are being used to get rid of this drawback (Miao et al., 2012). Suitable soil amendments play an important role in enhancing phytoremediation efficiency by stimulating plant growth and enhancing metal accumulation in shoots (Quartacci et al., 2007). It is one of the successful and mostly used chelating agent (Munn et al., 2008)). However, there is a lack of studies on using EDTA combined with giant reed (Arundo donax). In light of the above the present investigation was carried out with an objective to explore the potential of Arundo donax tolerance and investigate $\mathrm{Cd}$ uptake ability of roots and shoots of Arundo donax with or without EDTA.

\section{Materials and Methods}

Experimental set up : A pot experiment was set up in green house of Directorate of Weed Research Jabalpur in 2013. Rhizomes of Giant reed ( $A$. donax L.) were collected from the DWR nursery and were planted in rooting beds filled with soil. After 15 days, 54 rhizome cuttings of $10 \mathrm{~cm}$ long were selected carefully to have uniformity, bearing one plant each, with a stem of $15 \mathrm{~cm}$ height and $51 \mathrm{~mm}$ in diameter. All other rhizome buds were removed. Each selected rhizome was transplanted to a $2 \mathrm{~kg}$ capacity plastic pot filled with germinating sand (>2 mm). During growing periods, one stem per pot was retained. The position of each pot was changed at weekly interval so that each pot are uniformly exposed to sunlight. $\mathrm{Cd}$ containing aqueous solution was prepared by cadmium nitrate salt $\left(\mathrm{Cd}\left(\mathrm{NO}_{3}\right)_{2} \cdot 4 \mathrm{H}_{2} \mathrm{O}\right)$ in tap water. Cd treatments included 0 (control), 100, 200, 400, 800 and $1200 \mathrm{mg} \mathrm{l}^{-1}$ of cadmium nitrate. Ethylene diamine tetra-acetic acid (EDTA) concentrations were applied @ 0,3 and $6 \mathrm{mg} \mathrm{I}^{-1}$ six times. 
A completely randomized design was applied using 3 replication for each of the 18 treatments combinations.

Plant growth measurements : Various growth parameters including plant height $(\mathrm{cm})$, number of tillers, dry weight, leaf area, average root length $(\mathrm{cm})$ and visual toxicity symptoms after cadmium treatments were recorded. The physiological parameters included number of leaves and nondestructive chlorophyll measurements were performed using a chlorophyll meter at three stages (30, 45 and 60 days after planting) as per the method described by Dwyer et al. (1991). Chlorophyll content index $(\mathrm{CCl})$ of ear leaf were taken in each pot using a portable chlorophyll meter (SPAD-502 Plus). Total chlorophyll content in leaf was calculated by computing the $\mathrm{CCl}$ values in the equation established by Van den Berg and Perkins (2004).

Sample preparation and analytical methods : At 60th day after seedling transplant, plants were harvested and washed thoroughly with tap water followed by deionized water. The leaves of the plants were collected and measured for fresh weight and then dried at $70^{\circ} \mathrm{C}$ for 3 days. The dried plant samples were ground and mixed thoroughly for cadmium analysis. Plant samples $(1 \mathrm{~g})$ were digested in concentrated nitric and perchloric acid (3:1) till a clear solution was obtained. Three replicates of all the samples were run to ensure precision of the determinations. Solution was filtered, reconstituted to the desired volume and analyzed cadmium in di-acid plant extract by atomic absorption spectrophotometer (Thermo Solar- S4 model). Data on metal concentrations and accumulations of the samples were presented as mean \pm standard deviation of three replicative tests.

Statistical analysis : Data were analysed using analysis of variance (ANOVA) and the statistical significance of the differences between treatment means between control and treatments was determined by means of the Scheffe test $(\mathrm{pb}<$ $0.05)$. Fisher $L S D$ test was used for comparison of the treatments.

\section{Results and Discussion}

After cultivation, no significant change was observed in shoot heights of Arundo exposed at $400 \mathrm{mg} \mathrm{l}^{-1} \mathrm{Cd}$ (Table 1). However, beyond $400 \mathrm{mg} \mathrm{l}^{-1}$, the length of roots was significantly affected at 800 and $1200 \mathrm{mg} \mathrm{l}^{-1}$. (Table2). As compared with control, the dry weight of shoots was at par with each other at 100 , 200 and $400 \mathrm{mg} \mathrm{l}^{-1}$. Although the concentrations of $\mathrm{Cd}$ in the pot increased sequentially from 100 to 400 , the dry biomass of plant shoots in these treatments was still high and the plants were still able to grow with big biomass. However, the dried biomass of plant shoots under 800 to $1200 \mathrm{mg} \mathrm{l}^{-1}$ of $\mathrm{Cd}$ was significantly $(P<$ $0.05)$ reduced as compared to lower levels of $\mathrm{Cd}\left(<400 \mathrm{mg} \mathrm{l}^{-1}\right)$. Similarly, no change in the leaf area of plant was observed upto $400 \mathrm{mg} \mathrm{l}^{-1}$ but the leaf area was reduced at higher level of $\mathrm{Cd}$ treatment. A number of studies on exposure of plants to elevated $\mathrm{Cd}$ levels have shown similar results. Arundo grown by and large at similar Cd concentration (358 ppm) in soil by (Papazoglou et al., 2005) showed no detrimental or toxic symptoms in terms of plant height, diameter and number of nodes in plant. In the present study at further elevated level of $800 \mathrm{ppm} \mathrm{Cd} \mathrm{did} \mathrm{not} \mathrm{affect}$ plant growth except for root length of Arundo.

Cadmium is highly toxic to plants. Inhibited growth of bean plants grown at 50 ppm in soil (Andon et al., 2005), sensitive to salvinia (Phetsombat et al., 2006) and hydrilla (Singh et al., 2013). On the contrary, results of the present study showed that Arundo donax L. had an exceptional ability to tolerate $\mathrm{Cd}$ in terms of growth response to external Cd level upto $400 \mathrm{mg} \mathrm{l}^{-1}$. The plants showed no visible symptoms of metal induced toxicity and no reduction of shoot and root dry matter yields were observed when plants were grown with $\mathrm{Cd}$ levels up to $400 \mathrm{mg} \mathrm{l}^{-1}$. The growth of grass species like Typha angustifolia and Lolium perenne were also observed unaffected by high $\mathrm{Cd}$ level (Chayapan et al., 2015). Yang et al., (2004) reported no reduction in growth of Sedum alfredi in terms of its shoot and root dry matter yield when the plant was exposed at Cd supply levels upto $200 \mu \mathrm{mol} \mathrm{I}^{-1}$ in nutrient solution. In the present work, Arundo showed $\mathrm{Cd}$ tolerance ability upto $400 \mathrm{mgl}^{-1}$, which was higher than the $100 \mathrm{mg}$ $\mathrm{I}^{-1}$ reported by GUO Zhao-hui and MAO Xu-feng (2010). At this concentration the tolerance was reflected with no adverse effect in terms of plant height, root length, dry weight and root biomass (Table 2). Due to absence of side roots, the flux of nitrate in presence of higher cadmium ion in solution might have affected the root length and root biomass.

EDTA at $3 \mathrm{mg} \mathrm{l}^{-1}$ enhanced the plant height, than grown in control. With regard to other parameters, EDTA at $3 \mathrm{mg} \mathrm{l}^{-1}$ increased dry weight and root length as compared to control, while there was no significant difference in leaf area and root biomass under EDTA treatment. Similar enhancement of Arundo growth were also observed by Yang et al., (2012) when EDTA was applied at $5.0 \mathrm{mmol} \mathrm{kg}^{-1}$ to giant reed. However, EDTA application at higher rate $\left(6 \mathrm{mg} \mathrm{l}^{-1}\right)$ visibly affected plant height, dry wight, root length, root biomass and leaf area (Table 2). The adverse effect of EDTA at higher concentration on barley plant was also recorded by Ali et al. (2006) and the effect was more pronounced at higher level of EDTA on shoot and root length of sunflower (Azhar et al. 2006).

In stem of Arundo, Cd concentration was 249.9, 285.6 and $292.6 \mathrm{mg} \mathrm{kg}^{-1}$ respectively, at 100, 200 and $400 \mathrm{mg} \mathrm{l}^{-1}$ which was statistically at par with each other. A significant difference $(p<0.05)$ in Cd uptake in stem was observed beyond $400 \mathrm{mg} \mathrm{l}^{-1}$. Cd uptake was 320.7 and $398.5 \mathrm{mg} \mathrm{kg}^{-1}$ in stem and 224.3 and $277.9 \mathrm{mg} \mathrm{kg}^{-1}$ in leaf at 800 and $1200 \mathrm{mg} \mathrm{l}^{-1} \mathrm{Cd}$ treatment. Similar trend of $\mathrm{Cd}$ accumulation was observed in leaf of Arundo (Table 3). Cd accumulation in root was $340.1,1626.5,2319.1,3481.1$ and $2485.7 \mathrm{mg} \mathrm{kg}^{-1}$ at $100,200,400,800$ and $1200 \mathrm{mg} \mathrm{l}^{-1}$ respectively. 
Table 1: Effect of cadmium levels and EDTA on height $(\mathrm{cm})$ of Arundo donax at different days of planting of arundo donax

\begin{tabular}{lllll}
\hline Cadmium levels $\left(\mathbf{m g ~ l}^{-1}\right)$ & 15 DAP & 30 DAP & 45 DAP & 60 DAP \\
\hline 0 & 22.55 & 23.32 & 23.44 & 24.32 \\
100 & 21.67 & 21.96 & 22.35 & 22.36 \\
200 & 25.14 & 25.85 & 25.43 & 25.04 \\
400 & 24.12 & 25.10 & 25.78 & 25.10 \\
800 & 24.05 & 25.08 & 25.18 & 25.78 \\
1200 & 24.11 & 25.54 & 24.58 & 24.15 \\
LSD $(P=0.05)$ & NS & & NS & NS \\
EDTA $\left(\mathrm{mg} \mathrm{l}^{-1}\right)$ & & 25.61 & 25.55 & 25.43 \\
0 & 24.96 & 25.93 & 26.18 & 26.51 \\
3 & 25.14 & 21.89 & 21.66 & 21.44 \\
6 & 20.72 & 3.30 & 3.18 & 3.352 \\
LSD $(P=0.05)$ & 3.19 & 8.105 & 3.85 & 8.211 \\
CdXEDTA & 7.83 & & & \\
\hline
\end{tabular}

DAP= Days after planting; NS=Non significant

Table 2: Effect of cadmium levels on growth parameters of Arundo donax

\begin{tabular}{lllll}
\hline Cadmium nitrate conc. & Dry weight $(\mathrm{g}$ per pot) & Leaf area $\left(\mathbf{c m} \cdot \mathbf{m}^{-2}\right)$ & Root length $(\mathbf{c m})$ & Root biomass $(\mathrm{g}$ per pot) \\
\hline 0 & 4.03 & 90.6 & 41.80 & 9.0 \\
100 & 3.96 & 124.2 & 42.23 & 10.0 \\
200 & 3.91 & 137.8 & 47.35 & 11.1 \\
400 & 124.6 & 44.01 & 13.1 \\
800 & 3.01 & 112.4 & 38.75 & 10.0 \\
1200 & 3.52 & 89.80 & 30.14 & 7.0 \\
LSD $(\mathrm{P}=0.05)$ & 3.19 & 29.89 & 8.25 & $\mathrm{NS}$ \\
0 & 0.103 & 119.6 & 47.92 & 11.33 \\
3 & 3.72 & 97.54 & 38.80 & 10.11 \\
6 & 4.27 & 21.13 & 35.43 & 8.66 \\
LSD $(\mathrm{P}=0.05)$ & 3.32 & 7.05 & $\mathrm{NS}$ \\
\hline
\end{tabular}

Cd concentration (except at 800 to $1200 \mathrm{mg} \mathrm{l}^{-1}$ ) changed little in the above ground part of leaves and stems when the plants were supplied with less than $400 \mathrm{mg} \mathrm{l}^{-1} \mathrm{Cd}$ for 60 days. Whereas, $\mathrm{Cd}$ concentration in roots of $A$. donax increased sharply with increasing external $\mathrm{Cd}$ supply levels, peaked at $800 \mathrm{mg} \mathrm{l}^{-1}$ and then decreased with further increased in $\mathrm{Cd}$ level. According to Baker et al., (2000), cadmium hyperaccumulator is defined as plant species capable of accumulating more than $100 \mathrm{mg} \mathrm{Cd} \mathrm{kg}^{-1}$ in the shoot dry weight. So far, only few $\mathrm{Cd}$ hyperaccumulators have been identified as Thalspi caerulescens and Arabidopsis halleri (Lombi et al., 2000; Kupper et al., 2000). In this study, Cd uptake was 320.7 and $398.5 \mathrm{mg} \mathrm{kg}^{-1}$ in stem and 224.3 and 277.9 $\mathrm{mg} \mathrm{kg}^{-1}$ in leaf at 800 and $1200 \mathrm{mg} \mathrm{l}^{-1}$ respectively. The $\mathrm{Cd}$ accumulation was 249.9 and $173.0 \mathrm{mg} \mathrm{kg}^{-1}$ at $100 \mathrm{mg} \mathrm{l}^{-1}$ in stem and leaf respectively, which was significantly higher as compared with $\mathrm{Cd}$ accumulation at exposed higher dose of $800-1200 \mathrm{mg} \mathrm{l}^{-1}$ (Fig. 1).

Giant reed (Arundo donax) possess a typical ability of $\mathrm{Cd}$ hyperaccumulation, characterized by bio-concentration factor. Bioconcentration factor of shoot and root was 2.406 and 1.059 at 100 $\mathrm{mg} \mathrm{I}^{-1}$. With increasing $\mathrm{Cd}$ concentration in solution, bio concnetration factor of root increased, whereas it decreased in shoot. Higher bioconcentration factor was peaked in root (2.471) at $800 \mathrm{mg} \mathrm{l-}{ }^{-1} \mathrm{Cd}$ exposed and thereafter decreased at $1200 \mathrm{mg} \mathrm{I}^{-1}$ (Table 3). Significant response of $\mathrm{Cd}$ accumulation by root over above ground parts might be due to the contact of root exposed in aqueous solution by which Arundo root absorbed Cd linearly (Fig 1). The findings of Papazoglou (2007) showed that $\mathrm{Cd}$ concentration in the shoots of $A$. donax reached as high as $973.8 \mathrm{mg} \mathrm{kg}^{-1} \mathrm{Cd}(\mathrm{DW})$ at the end of $2^{\text {nd }}$ year when exposed at higher concentration of $\mathrm{Cd}$ (100 $\mathrm{mg} \mathrm{l}^{-1}$ ) and were as high as $300 \mathrm{\mu g} \mathrm{g}^{-1}$ in root even at $1000 \mathrm{Mg} \mathrm{Cd} \mathrm{l}^{-1}$ $\left(1 \mathrm{mg} \mathrm{l}^{-1}\right)$ in the hydroponic solution (Sabeen et al., 2013). Conversely, lower shoot/root $\mathrm{Cd}$ ratio $(<1)$ in the present investigation implies that $A$ rundo was exposed to higher dosing rate as compared with the treatments imposed by Sabeen et al., (2013).

Uptake of $\mathrm{Cd}$ by Arundo was ranged from of 240.6 to $372.9 \mathrm{mg} \mathrm{kg}^{-1}$ in shoot and 105.9 to $2226.7 \mathrm{mg} \mathrm{kg}^{-1}$ dry weight in roots when exposed to $\mathrm{Cd}$ (without EDTA). Application of EDTA further increased $\mathrm{Cd}$ uptake in roots than shoots (Table 4). At higher treatment ( $800 \mathrm{mg} \mathrm{l}^{-1} \mathrm{Cd}$ ), the shoot $\mathrm{Cd}$ concentrations reached, $363.9,264.9 \mathrm{mg} \mathrm{kg}^{-1}$ after $3.0,6.0 \mathrm{mg} \mathrm{l}^{-1}$ of EDTA as compared with $333.2 \mathrm{mg} \mathrm{l}^{-1} \mathrm{Cd}$ without EDTA treatment. The root 
Table 3: Cadmium accumulation in different plant parts and its bio-concentration factor and shoot/ root ratio of Arundo donax

\begin{tabular}{|c|c|c|c|c|c|}
\hline \multirow{2}{*}{$\begin{array}{l}\text { Treatments } \\
\mathrm{Cd}\left(\mathrm{mgl}^{-1}\right)\end{array}$} & \multicolumn{2}{|c|}{$\mathrm{Cd}\left(\mathrm{mg} \mathrm{kg}^{-1} \mathrm{DW}\right)$} & \multicolumn{2}{|c|}{ Bio- concentration factor } & \multirow{2}{*}{$\begin{array}{l}\text { Shoot/ root } \\
\text { ratio }\end{array}$} \\
\hline & shoot & root & shoot & root & \\
\hline 100 & 249.9 & 340.1 & 2.406 & 1.059 & 0.735 \\
\hline 200 & 285.6 & 1626.5 & 1.444 & 1.960 & 0.175 \\
\hline 400 & 292.2 & 2319.1 & 0.633 & 1.941 & 0.126 \\
\hline 800 & 320.7 & 3481.1 & 0.416 & 2.471 & 0.092 \\
\hline 1200 & 398.5 & 2485.7 & 0.311 & 1.855 & 0.160 \\
\hline $\operatorname{LSD}(P=0.05)$ & 56.18 & 475.0 & - & - & - \\
\hline
\end{tabular}

Table 4 : Interaction effect between cadmium levels and EDTAon Cd accumulation by shoot and root of Arundo donax

\begin{tabular}{|c|c|c|c|c|c|c|c|c|}
\hline \multirow{3}{*}{$\begin{array}{l}\text { Cadmium } \\
\text { nitrate } \\
\left(\mathrm{mg} \mathrm{kg}^{-1}\right)\end{array}$} & \multicolumn{4}{|c|}{ Cd accumulation in shoot } & \multicolumn{4}{|c|}{ Cadmium accumulation in root } \\
\hline & \multicolumn{3}{|c|}{ EDTA levels (mgl $\left.\mathrm{l}^{-1}\right)$} & \multirow[b]{2}{*}{ Mean } & \multicolumn{3}{|c|}{ EDTAlevels (mg l-1) } & \multirow[b]{2}{*}{ Mean } \\
\hline & 0 & 3 & 6 & & 0 & 3 & 6 & \\
\hline $\mathrm{Cd} 100$ & 240.6 & 300.2 & 209.0 & 249.9 & 105.9 & 245.7 & 668.7 & 340.1 \\
\hline $\mathrm{Cd} 200$ & 288.9 & 299.5 & 268.5 & 285.6 & 392.0 & 835.3 & 3652.3 & 1626.5 \\
\hline $\mathrm{Cd} 400$ & 253.1 & 357.9 & 265.7 & 292.2 & 777.4 & 3095.6 & 3084.3 & 2319.1 \\
\hline $\mathrm{Cd} 800$ & 333.2 & 363.9 & 264.9 & 320.7 & 1976.6 & 3941.6 & 4225.1 & 3481.1 \\
\hline Cd 1200 & 372.9 & 338.3 & 484.2 & 398.5 & 2226.7 & 2523.3 & 2707.1 & 2485.7 \\
\hline Mean & 297.7 & 331.9 & 298.4 & - & 1095.7 & 2128.3 & 2927.5 & - \\
\hline
\end{tabular}

For Shoot: LSD ( $P=0.05)$ : Cd levels=56.18; Ed levels=NS; Cd x Ed ( $P=0.05)=97.32 ;$ For Root: $\operatorname{LSD}(P=0.05)$ : Cd levels=575.0; Ed levels=445.4; $C d x$ $\operatorname{Ed}(P=0.05)=996.04$

Table 5 : Bioaccumulation coefficient (BC) of $\mathrm{Cd}$ in shoot and root at different EDTAlevels

\begin{tabular}{|c|c|c|c|c|c|c|}
\hline \multirow{3}{*}{$\begin{array}{l}\text { Cadmium nitrate } \\
\left(\mathrm{mgl}^{-1}\right)\end{array}$} & \multicolumn{3}{|c|}{$B C$ of $C d$ in shoot } & \multicolumn{3}{|c|}{$\mathrm{BC}$ of $\mathrm{Cd}$ in root } \\
\hline & \multicolumn{3}{|c|}{ EDTAlevels } & \multicolumn{3}{|c|}{ EDTA levels } \\
\hline & 0 & 3 & 6 & 0 & 3 & 6 \\
\hline $\mathrm{Cd} 100$ & 2.406 & 3.002 & 2.090 & 1.059 & 2.457 & 6.687 \\
\hline $\mathrm{Cd} 200$ & 1.444 & 1.497 & 1.343 & 1.960 & 4.176 & 18.260 \\
\hline $\mathrm{Cd} 400$ & 0.633 & 0.895 & 0.664 & 1.941 & 7.739 & 7.711 \\
\hline $\mathrm{Cd} 800$ & 0.416 & 0.455 & 0.331 & 2.471 & 4.927 & 5.281 \\
\hline $\mathrm{Cd} 1200$ & 0.311 & 0.282 & 0.404 & 1.855 & 2.103 & 2.256 \\
\hline
\end{tabular}

Cd concentrations were $3941.6,4225.1 \mathrm{mgl}^{-1}$ when $3.0,6.0 \mathrm{mgl}^{-1}$ of EDTA was applied as compared with $1976.6 \mathrm{mg} \mathrm{l}^{-1} \mathrm{Cd}$ with no EDTA application (Fig. 1 and 2). The results of the present investigation are in consistence with the studies of Liphadzi and Kirkham(2006).

Bioaccumulation coefficient $(\mathrm{BC})$ was used to evaluate the potential of Arundo to remediate $\mathrm{Cd}$ from soil. The $\mathrm{BC}$ of Arundo root was higher than its shoot. At $100 \mathrm{mg} \mathrm{l}^{-1}$, addition of EDTA at $3 \mathrm{mg} \mathrm{l}^{-1}$ increased BC from 2.406 (control) to 3.002 in shoot and from 1.059 (Control) to 2.457 in root. At $200 \mathrm{mg} \mathrm{l}^{-1} \mathrm{Cd}$, the addition of EDTA increased BC from 1.444 to 1.497 in shoot and from 1.960 to 4.176 in root at $3 \mathrm{mg} \mathrm{l}^{-1}$. Beyond $200 \mathrm{mg} \mathrm{l}^{-1}$ dose, the $B C$ value decreased with corresponding increase of cadmium and EDTAlevels (Table 5).
$400 \mathrm{mg} \mathrm{l}^{-1} \mathrm{Cd}$ concentration, EDTA enhanced more BC value in root than shoot. The bioaccumulation coefficient of Arundo root at $400 \mathrm{mg} \mathrm{l}^{-1} \mathrm{Cd}$ increased from 1.94 (control) to 7.73 and 7.71 at 3.0 and $6.0 \mathrm{mg} \mathrm{l}^{-1}$ of EDTA (Table 5). However, the bioconctration factor of shoot at $400 \mathrm{mg} \mathrm{I}^{-1} \mathrm{Cd}$ increased from 0.633 to 0.895 and 0.664 at 3 and $6 \mathrm{mg} \mathrm{l}^{-1}$ of EDTA, respectively. Beyond $400 \mathrm{mg} \mathrm{l}^{-1}$, lesser shoot uptake and higher root bioconcentration factor $(\mathrm{BC})$ of Arundo was due to retention of $\mathrm{Cd}$ more in roots than shoots as evident from Table 3. Turan and Esringu (2007) also recorded more accumulation of metal in root than shoot in Brassica junceae exposed at $\mathrm{Pb}$ levels in presence of EDTA. EDTA is one of the successful chemical reagent because it is a powerful, recoverable and comparatively biostable chelator which has ability to remediate soil. In highly $\mathrm{Cd}$ rich rock phosphate, a source of $\mathrm{Cd}$ contamination in phosphatic fertilizer, 


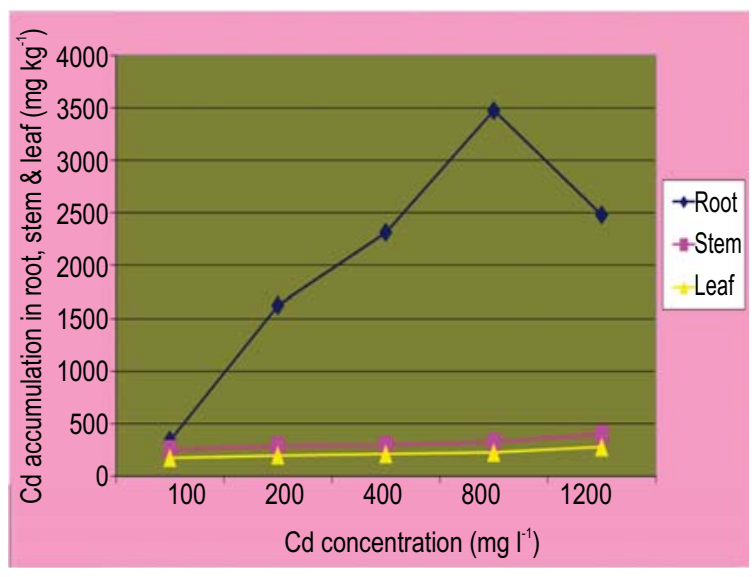

Fig. 1 : Cadmium accumulation by different parts of Arundo donax

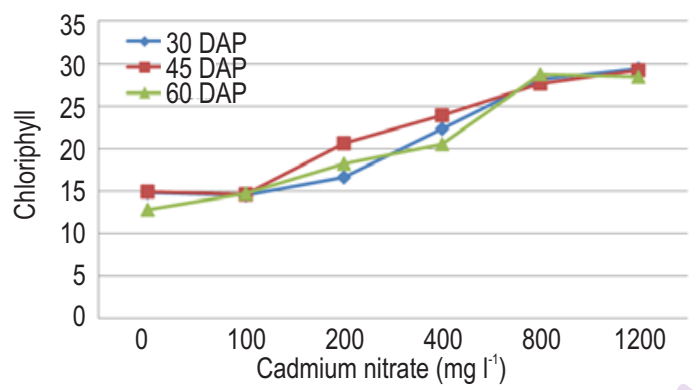

Fig. 3 : Effect of cadmium nitrate on chlorophyll reflectance at different stages of Arundo donax

optimum dose of EDTA at $3 \mathrm{mg} \mathrm{l}^{-1}$ has implications for increasing the bio-availabilty vis-a-viz to boost $\mathrm{Cd}$ absorption by root of fast growing weedy plant, Arundo donax. These results are in line with the findings of Zhang et al. (2012) and Alvarenga et al. (2008), plant candidates for phytostabilization should possess an extensive root system and a large amount of biomass with translocation of metals from roots to shoots as low as possible at higher concentration.

There was no big difference of $\mathrm{Cd}$ accumulation between 3 and $6 \mathrm{mg} \mathrm{l}^{-1}$ of EDTA. The optimum dose of $3 \mathrm{mg} \mathrm{I}^{-1}$ EDTA at enhanced $\mathrm{Cd}$ accumulation was at par with $6 \mathrm{mg} \mathrm{I}^{-1}$. Moreover, application @ $6 \mathrm{mg} \mathrm{l}^{-1}$ of EDTA reduced the root length and root biomass. These results are also supported by the findings of Zhao et al. (2011) that the plant biomass decreased at higher dose of 4 $\mathrm{mmol} \mathrm{kg}$.

Although both plants are grassy belong to same family Poaceae but differ in shoot quality. Chlorophyll production decreased over increasing level of EDTA may be due to soft shoot of Lolium multiflorum against semi-hardy shoot of Arundo donax.

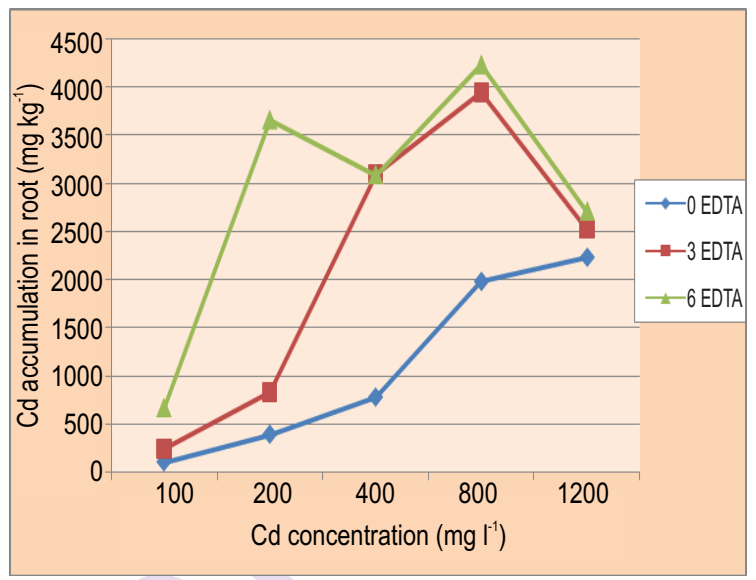

Fig. 2: Cadmium uptake by roots of Arundo donax under EDTAlevels

EDTA not only increased the growth in terms of plant dry weight, leaf area, uptake of cadmium but the chelate may have also sequesterd the metal in semi-hardy shoot in a way that protected the Arundo from some of the toxic effects thereby promoting continued chlorophyll production. Similar induced effect of EDTA on chlorophyll of plant was also reported by Miller et al. (2016). The chlorophyll content index $(\mathrm{CCl})$ of plant significantly increased with increasing cadmium levels beyond $200 \mathrm{mg} \mathrm{l}^{-1}$ as compared with control. The $\mathrm{CCl}$ in leaf after 30 days increased significantly from 14.84 in control to $16.60,22.30,28.21$ at 200, $400,800 \mathrm{mg} \mathrm{l}^{-1} \mathrm{Cd}$ respectively. The CCl at 1200 and $800 \mathrm{mg} \mathrm{l}^{-1}$ was at par at 30 days of plant. Among the different stages of plant, Arundo at 45 days showed higher total chlorophyll and $\mathrm{CCl}$ to $\mathrm{Cd}$ concentration in the range of $100-800 \mathrm{mg} \mathrm{l}^{-1}$ (Fig 3). A linear relationship between $\mathrm{CCl}$ and estimated chlorophyll for a sugar maple (Acer saccharum) was reported by Berg and Perkins (2004). Acer saccharum is a fast growing plant like Arundo donax and both the species are grown in north west region of India. The total chlorophyll content in leaf was increased significantly from 0.31 in control to $0.3831,0.4282,0.4783 \mathrm{mg} \mathrm{mm}^{-2}$ at 200, 400,800 $\mathrm{mg} \mathrm{l-}{ }^{1} \mathrm{Cd}$, respectively at 45 days. The increasing trend of total chlorophyll and $\mathrm{CCl}$ with respective to $\mathrm{Cd}$ application was associated with the supply of nitrate from cadmium nitrate, a $\mathrm{Cd}$ source used for plant exposure. The source of nitrogen increased chlorophyll in leaf was also confirmed by Hokmalipour and Darbandi (2011) in maize supplied with $\mathrm{N}$ fertilizer.

The total chlorophyll content in leaf at 45 days increased significantly from 0.3731 in control to 0.4075 and 0.4175 when EDTA was applied 3 and $6 \mathrm{mg} \mathrm{l}^{-1}$ respectively. Thus, no adverse effect of EDTA was recorded both on $\mathrm{CCl}$ and chlorophyll content. These results are consistent with the findings of Ma et al., (2006) where, no significant change with EDTA was observed on chlorophyll content when EDTA @ 3 mmol x kg ${ }^{-1}$ was added to plants grown in sediment at one time only. However, they reported that when the same level of EDTA were applied three times, the 
chlorophyll content was reduced to $48 \%$ but in respect of chlorophyll in Arundo, no adverse effect of EDTA was observed on chlorophyll reduction even at higher dose $\left(6 \mathrm{mg} \mathrm{l}^{-1}\right)$ applied 6 times during the experimentation.

Summarizing, $\mathrm{Cd}$ accumulated to higher extent by Arundo without showing any adverse effect on its growth terms of plant height, biomass and leaf area. The plant is useful for the treatment of $\mathrm{Cd}$ contaminated sewage and industrial wastewaters prior to irrigation use for vegetables. Arundo donax with optimum level of EDTA has also potential use for decadmiation of rock phosphate as raw source of phosphatic fertilizers.

\section{Acknowledgments}

This study was supported as a scientific research project (WQ-3032) by the National Fund of Basic Strategic Frontier Areas Research in Agriculture (NFBSFARA) of Indian Council of Agricultural Research, New Delhi.

\section{References}

Alvarenga, P., A.P. Gonçalves, R.M. Fernandes, A.D. Varennes, G. Vallini, E. Duarte and A.C. Cunha Queda: Evaluation of composts and liming materials in the phytostabilization of a mine soil using perennial ryegrass. Sci. Total Environ., 406, 43-56 (2008).

Azhar, N.M., Y. Ashraf, M. Hussain and F. Hussain: Phytoextraction of lead application through sunflower cultivation: Seedling growth studies. Pale J. Bot., 38, 1551-1560 (2006).

Baker, AJ.M., S.P. McGrath., R.D. Reeves., J.A.C. Smith: Metal hyper accumulator plants: A review of ecology and physiology of a biological resource for phytoremediation of metal-polluted soils. In: Phytoremediation of contaminated soil and water (Eds.: N. Terry and G. Banuelos). USA 1 Lewis Publisher (2000).

Berg, A.K.V.D. and T.D. Perkins: Evaluation of a portable chlorophyll meter to estimate chlorophyll and nitrogen contents in sugar maple (Acer saccharum Marsh.) leaves. Forest Ecol. Manag., 200, 113-117 (2004).

C.P.C.B: Cadmium-An Environment Toxicant-March 2007. Newsletter, p. 30 (2007).

Chayapan, P., M. Kruatrachue, M. Meetam and P. Pokethitiyook: Phytoremediation potential of $\mathrm{Cd}$ and $\mathrm{Zn}$ by wetland plants, Colocasia esculenta Schott., Cyperus malaccensis Lam., and Typha angustifolia L. grown in hydroponics. J. Environ. Biol., 36, 1179-1183(2015).

Demirezen, D. and A. Aksoy: Accumulation of heavy metals in Typha angustifolia (L.) and Potamogeton pectinatus (L.) living in Sultan Marsh (Kayseri,Turkey). Chemoaphere, 56, 685-696 (2004).

Dwyer, L.M., M. Tollenaar and L. Houwing: A non-destructive method to monitor leaf greenness in corn. Can. J. Plant Sci., 71, 505-509 (1991).

Guo, Z.H. and X.F. Miao: Growth changes and tissues anatomical characteristics of giant reed (Arondo donax. $L$ ) in soil contaminated with arsenic, cadmium and lead. J. Cent. South Univ. Technol., 17, 770-777 (2010).

Hokmalipour, S. and M.H. Darbandi: Effects of nitrogen fertilizer on chlorophyll content and other leaf indicate in three cultivars of maize (Zea mays L.). Wor. Appli. Sci. J., 15, 1780-1785 (2011).
İlbaş, A.I.., Y. Eroğlu and H.E. Eroğlu: Effects of dosages and application periods of EDTA on morphological and cytogenetic characters of barley (Hordeum vulgare L.) seedlings. Turk. J. Biol., 30, 59-63 (2006).

Indian Bureau of Mines: Indian Minerals Yearbook 2011 (part- ii). Edn., $50^{\text {th }}$, Cadmium Advance Release Government of India Ministry of Mines Indian Bureau of Mines Indira Bhavan, Civil Lines, Nagpur, 52,1-23(2012).

Khankhane, P.J. and J.G. Varshney: Lead and manganese accumulation by weeds at heavy metal contaminated sites in Jabalpur. Ind. J. Weed Sci., 43, 224-225 (2011).

Kupper, H., E. Lombi, F.J. Zhao and S.P. McGrath: Cellular compartmentation of cadmium and zinc in relation to other elements in the hyperaccumulator Arabidopsis halleri. Planta, 212, 75-84 (2000).

Lane E.A., M.J. Canty and S.J. More: Cadmium exposure and consequence for the health and productivity of farmed ruminants. Res. Veterin. Sci., 101, 132-139 (2015).

Liphadzi, M.S. and M.B. Kirkham: Availability and plant uptake of heavy metals in EDTA-assisted phytoremediation of soil and composted biosolids. South Afr. J. Bot., 72, 391-397 (2006).

Lombi, E., F.J. Zhao, S.J. Dunham and S.P. McGrath: Cadmium accumulation in populations of Thlaspi caerulescens and Thlaspi goesingense. New Phytol., 145, 11-20 (2000).

Ma, W.F., X.H. Zhao, J.M. Sun and R. Li: Roles of EDTA on phytoremediation of combined contamination in dredged sewage river sediment. Huan Jing Ke Xue, 27, 85-90 (2006).

Mar, S.S. and M. Okazaki: Investigation of $\mathrm{Cd}$ contents in several phosphate rocks used for the production of fertilizer. Microchem. J., 104, 17-21 (2012).

Marshall, F.M., J. Holden, C. Ghose, B. Chisala, E. Kapungwe, J. Volk, M. Agrawal, R. Agrawal, R.K. Sharma and R.P. Singh: Contaminated irrigation water and food safety for the urban and peri-urban poor: Appropriate measures for monitoring and control from field research in india and zambia, incpetion report DFID enkar R8160, SPRU, University of Sussex. <www. pollutionandfood.net> (2007).

Martin, T.A. and M.V. Ruby: Review of in situ remediation technologies for lead, zinc and cadmium in soil. Remediation, 14, 35-53 (2004).

Merry, R.H. and K.G. Tiller: Distribution and budget of cadmium and lead in an agricultural region near Adelaide, South Australia. Water Air Soil Pollut., 57/58,172-180 (1991).

Miller, G., C. Davis, G. Begonia and M. Begonia: Metal uptake, growth responses and chlorophyll production of wheat (Triticum aestivum) exposed at different durations to chelate-amended cadmiumcontaminated soils. World Environ., 6, 10-18 (2016).

Mirza, N., Q. Mahmood, A. Pervez, R. Ahmad, R. Farooq, M.M. Shah and M.R. Azim: Phytoremediation potential of Arundo donax $L$ in arsenic contaminated synthetic wastewater. Biores. Technol., 101, 5815-5819 (2010).

Mujahid, F., S. Ali, M.B. Shakoor, S.A. Bharwana, H. Rizvi, S. Ehsan, H.M. Tauqeer, U. Iftikhar and F. Hannan: EDTA assisted phytoremediation of cadmium, lead and zinc. Int. J. Agron. Plant Product., 4, 2833-2846 (2013).

Munn, J., M. January and T.J. Cutright: Greenhouse evaluation of EDTA effectiveness at enhancing $\mathrm{Cd}, \mathrm{Cr}$ and $\mathrm{Ni}$ uptake in Helianthus annuus and Thlaspi caerulescens. J. Soils Sedi., 8, 116-122 (2008).

Murthy, N., S.K. Panda, D.I. Khasim and R. Banodiya: Monitoring of cadmium accumulation in Cephalopods processed in Gujarat 
coast. Asian Fisher. Sci., 22, 319-330 (2009).

Papazoglou, E.G., G.A. Karantounias, S.N. Vemmos and D.L. Bouranis: Photosynthesis and growth responses of giant reed (Arundo donax L.) to the heavy metals $\mathrm{Cd}$ and Ni. Envir. Intern., 31, 243-249 (2005).

Papazoglou, E.G.: Arundo donax L. stress tolerance under irrigation with heavy metal aqueous solutions. Desalination, 211, 304-313 (2007).

Phetsombat, S., M. Kruatrachue, P. Pokethitiyook and S. Upatham: Toxicity and bioaccumulation of cadmium and lead in Salvinia cucullata. J. Envir. Biol., 27, 645-652 (2006).

Prabavathi, R., V. Mathivanan and Selvisabanayagam: Analysis of concentration and accumulation of heavy metal cadmium in four selected terrestrial plants. Inter. J. Develop. Res., 1, 27-30, (2011).

Quartacci, M.F., B. Irtelli, A.J.M. Baker and F. Navari-Izzo: The use of NTA and EDDS for enhanced phytoextraction of metals from a multiply contaminated soil by Brassica carinata. Chemosphere, 68, 1920-1928 (2007).

Sabeen, M., Q. Mahmood, M. Irshad, I. Fareed, A. Khan, F. Ullah, J. Hussain, Y. Hayat and S. Tabassum: Cadmium phytoremediation by Arundo donax L. from contaminated soil and water. BioMed Res. Intern., Article ID 324830: http://dx.doi.org/10.1155/20013/ 324830 (2013).

Samra, J.S.: Heavy metal contaminated waters and their remediation for food safty. Souvenir of $10^{\text {th }}$ Inter Regional Conference on Water and Environment Organized by Indian Society of Water Management during October 17-20 at IARI, New Delhi, pp. 611(2007).

Singh, A., C.S. Kumar and A. Agarwal: Effect of lead and cadmium on aquatic plant Hydrilla verticillata. J. Environ. Biol., 34, 1027-1031 (2013).

Singh, K.P., D. Mohon, S. Sinha and R. Dalwani: Impact assessment of treated/ untreated wastewater toxicants discharge by sewage treatment plants on health, agricultural, and environmental quality in wastewater disposal area. Chemosphere, 55, 227-255 (2004).

Singh, O.V., S. Labana, G. Pandey, R. Budhiraja and R.K. Jain: Phytoremediation: an overview of metallic ion decontamination from soil. Appli. Microbio. Biotech., 61, 405-412 (2003).

Singh, R.P. and A. Kumar: Environmental exposures and toxic effects of cadmium: Areview. Asian J. Adv. Basic Sci., 3, 217-221 (2014).

Thayalakumaran, T., I. Vogeler, D.R. Scotter, B.H. Robinson, B.E. Clothier and S.R. Green: Chelation therapy for dirty soils. In Agronomy Abstracts. Am. Soc. Agronomy, Crop Sci. Soc. Am., Soil Sci. Soc. Am., Madison, Wl. 202 (2000).

Turan, M. and A. Esringu: Phytoremediation based on canola (Brassica napus L.) and Indian mustard (Brassica juncea L.) planted on spiked soil by aliquot amount of $\mathrm{Cd}, \mathrm{Cu}, \mathrm{Pb}$, and $\mathrm{Zn}$. Plant Soil Envir., 53, 7-15(2007).

Vassilev, A., B. Malgozata, S. Nevena and Z. Zlatko: Chronic Cd toxicity of bean plants can be partially reduced by supply of ammonium sulphate. J. Cent. Eur. Agric., 6, 389-396 (2005).

Wuana, R.A. and F.E. Okieimen: Phytoremediation potential of maize (Zea mays L.).Areview. Afri. J. Gen. Agri., 6, 275-287 (2010).

Yang, X.E., X.X. Long, H.B. Ye, Z.L. He, D.V. Calvert and P.J. Stoffella: Cadmium tolerance and hyperaccumulation in a new $\mathrm{Zn}$ hyperaccumulating plant species (Sedum alfredii Hance). Plant and Soil, 259, 181-189 (2004).

Yang, M., X. Xiao, X. Miao, Z. Guo and F.Y. Wang: Effect of amendments on growth and metal uptake of giant reed (Arundo donax L.) grown on soil contaminated by arsenic, cadmium and lead. Trans. Nonferrous Met. Soc. China., 22, 1462-1469 (2012).

Zhang, S., T. Li, H. Huang, T. Zou, X. Zhang, H. Yu, Z. Zheng and Y. Wang: $\mathrm{Cd}$ accumulation and phytostabilization potential of dominant plants surrounding mining tailings. Envir. Sci. Pollut. Res., 19, 3879-3888 (2012).

Zhao, H., L. Lin, Q. Yan, Y. Yang, X. Zhu and J. Shao: Effect of EDTA and DTPA and lead and zinc accumulation of ryegrass. J. Envir. Infect., 2, 932-939 (2011). 